\title{
FIXATION OF TARPAULIN SHEET OF PLATFORM HDV AND ITS IMPACT TO AIR RESISTANCE
}

\begin{abstract}
This paper due to determine an aerodynamic drag for different ways of tarpaulin fixation, specifically tarpaulin tension and disposition on platform-type body of a HDV. More positions of the tarpaulin were investigated. Determination of the resistances was done by coast down test of the vehicle according to Slovakian technical standard (STN). The aerodynamic drag was calculated from actual vehicle deceleration during the coast down test from the actual velocity changes. The vehicle actual velocity was measured by GPS logging device. Results are values of resistance, which affect the vehicle and their sum represents the actual engine power needed for vehicles driving. Keyword: aerodynamic drag, tarpaulin fixation, coast down test, platform goods vehicle
\end{abstract}

\begin{tabular}{|c|c|c|c|c|c|c|c|c|}
\hline Tomáš Skrúcaný1 & & & & & & & & \\
\hline $\begin{array}{l}{ }^{1} \text { University of Žilina, Univerzitná } \\
\text { tomas.skrucany@fpedas.uniza.sk }\end{array}$ & $8215 / 1$, & 010 & 26 & Žilina, & Slovakia; & +421 & 41513 & 3518; \\
\hline $\begin{array}{l}\text { Martin Vojtek }^{2} \\
{ }^{2} \text { University of Žilina, Univerzitná }\end{array}$ & $8215 / 1$, & 010 & 26 & Žilina, & Slovakia; & +421 & 41513 & 3434 \\
\hline $\begin{array}{l}\text { Gabriel Suchter } \\
\text { 3. }\end{array}$ & & & & & & & & \\
\hline $\begin{array}{l}{ }^{3} \text { University of Žilina, Univerzitná } \\
\text { gabriel.suchter@fpedas.uniza.sk }\end{array}$ & $8215 / 1$, & 010 & 26 & Žilin & Slovakia; & +421 & 41513 & 01; \\
\hline
\end{tabular}

\section{Introduction}

Tarpaulin platform-type bodies of road freight vehicles are currently the most used type of bodies (Rakovska 2016). It is mostly for their variability of usage, cost, technical simplicity and weight (Knez, Jereb, Obrecht 2014; Kalincak, Bartik, Grencik 2012). This type of body is very versatile, because it is easy to manipulate with it. We can change its position, tension and disposition therefore it is very adaptable for actual transport conditions. However, it could be the reason for increased fuel consumption of the vehicle, when we slovenly handle it (Skrucany, Sarkan, Gnap 2016; Van der Krieke, Van Raemdonck 2014; Mruzek, Gajdac, Kucera 2016; Vrábel, Jagelčák, Zamečník, Caban 2017; Sdoukopoulos, Boile, Anagnostopoulou 2015).

\section{Aerodynamic drag and fuel consumption}

A vehicle moves in exact time in exact space. A movement is dynamic action, which impacts to vehicle by resistances of surroundings are also dynamic (Kobryn, Figlus 2010; Matuszak 2012). In every instant, they have got different values. These values are influenced by ground (roadway), air (density, pressure, streaming), vehicle weight and movement (acceleration, deceleration, constant velocity). The sum of all resistances reflects a force, which acts against the movement of the vehicle (Kalina et al. 2017; Hausberger et al. 2011; Jazar 2009). Driving force of wheels must be equal to sum of resistances for ensuring vehicle movement. Driving force is created by vehicle engine. The smaller resistance acting to vehicle, the smaller driving force is needed. The engine expends smaller power therefore the immediate fuel consumption is smaller. Aerodynamic drag (air resistance) has the biggest impact just at high speed of vehicle. Nowadays, network of high-speed roads - highways - is extending so transport distance and transport speed are also extending. Consequently, air resistance is increasingly serious factor, which has got impact to fuel consumption (Rievaj, Mokrickova, Rievaj 2016; Polcar, Cupera, Kumbar 2016).

On the figure 1 , we can see a process of single resistances which has got impact to tested vehicle in consideration of its actual speed.

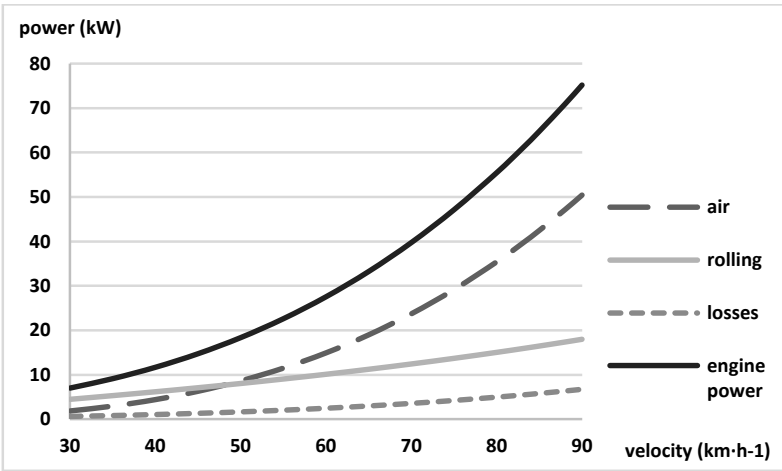

Fig. 1. Vehicle resistance powers

Curves indication air, rolling and transmissions express partial resistances which impact the vehicle. The sum of these resistances is overall resistance power (engine power) active during movement of vehicle, which the engine must expend in exact conditions for keeping vehicle in movement in required speed. These processes represent a two-axel vehicle with tarpaulin platform-type body, which weighs 12 tons (exact and for calculation considered weight is 11 tons) with usual tires, driver's cab with sleeping compartment. There are not any winds ahead or side winds and the vehicle is moving on flat road without slope. When the speed is $90 \mathrm{~km} \cdot \mathrm{h}^{-1}$, the engine must expend approximately $75 \mathrm{~kW}$. Vehicle engines of this category are in power classes from 130 to $190 \mathrm{~kW}$ so it can be around $40-60 \%$ of their maximal power. Very 
interesting is process of air resistance, which becomes dominant around $50 \mathrm{~km} \cdot \mathrm{h}^{-1}$. When the speed is higher, air resistance impact is increasing.

Table 1. Process of powers

\begin{tabular}{|c|c|c|c|c|c|c|}
\hline Type & \multicolumn{2}{|c|}{$50 \mathrm{~km} \cdot \mathrm{h}^{-1}$} & \multicolumn{2}{c|}{$70 \mathrm{~km} \cdot \mathrm{h}^{-1}$} & \multicolumn{2}{c|}{$90 \mathrm{~km} \cdot \mathrm{h}^{-1}$} \\
\hline \multirow{2}{*}{ Air } & $\begin{array}{c}8,7 \\
\mathrm{~kW}\end{array}$ & $\begin{array}{c}47 \\
\%\end{array}$ & $\begin{array}{c}23,8 \\
\mathrm{~kW}\end{array}$ & $\begin{array}{c}60 \\
\%\end{array}$ & $\begin{array}{c}50,6 \\
\mathrm{~kW}\end{array}$ & $\begin{array}{c}67 \\
\%\end{array}$ \\
\hline \multirow{2}{*}{ Rolling } & 8,1 & 44 & 12,4 & 31 & 18 & 24 \\
& $\mathrm{~kW}$ & $\%$ & $\mathrm{~kW}$ & $\%$ & $\mathrm{~kW}$ & $\%$ \\
\hline \multirow{2}{*}{ Losses } & 1,7 & \multirow{2}{*}{$9 \%$} & 3,6 & $9 \%$ & 6,8 & $9 \%$ \\
& $\mathrm{~kW}$ & & $\mathrm{~kW}$ & & $\mathrm{~kW}$ & \\
\hline Engine & 18,4 & & 39,8 & & 75,4 & \\
power & $\mathrm{kW}$ & & $\mathrm{kW}$ & & $\mathrm{kW}$ & \\
\hline
\end{tabular}

Size of air resistance is influenced by many physical factors, such as:

- Air density (depends on actual temperature and atmospheric pressure),

- Front surface of vehicle,

- Vehicle speed,

- Coefficient of air resistance $\mathrm{C}_{\mathrm{d}}$.

There are some factors, which cannot be influenced by operator or driver through transport. For instance air density is that factor, because it is surrounding state. Front surface of vehicle can be hardly influenced at tarpaulin platform-type body. Driver can directly influence the speed of vehicle but there are other factors, such as adhering schedule for loading or unloading goods. Coefficient of air resistance is a value, which changes considering to operating state of tarpaulin and its tension.

\section{Coast down test}

A coasting during which the vehicle is moving by inertia from the moment of neutral gear position shifting is decelerated due to the effect of driving resistances. This coast down test is done on the test track. Vehicle movement is direct and unevenly slowed during the test. Driving resistances are determined by calculation of the vehicle actual deceleration. It is also determined by known geometric characteristics of measured section and vehicle inertia parameters. Measured driving resistance of the vehicle and coasting characteristics are designated by calculation. This type of test reports to STN 300554 standard (Standard STN 30 0554) (Slovakian technical standard) and we proceeded in accordance with it. Some procedures were changed due to achievement of higher informative value of test results.

\section{Vehicle}

Vehicle MAN TGL 12.250 was used for measuring air resistance coefficient $c_{d}$. This freight vehicle is categorized as vehicle with overall weight 12 tons. Space for loading is covered by tarpaulin platform-type body. It is the most used variant with many benefits - simple manipulation during loading and unloading. The tarpaulin platform-type body could be rolled up therefore material with large sizes could be also loaded. This is not possible at box bodies, because they could be loaded only from the sides, which could be opened (usually doors from sides or back part of the vehicle. Transport companies have got lower inputs likewise lower operating costs, mainly costs for oil consumption and costs for maintenance.

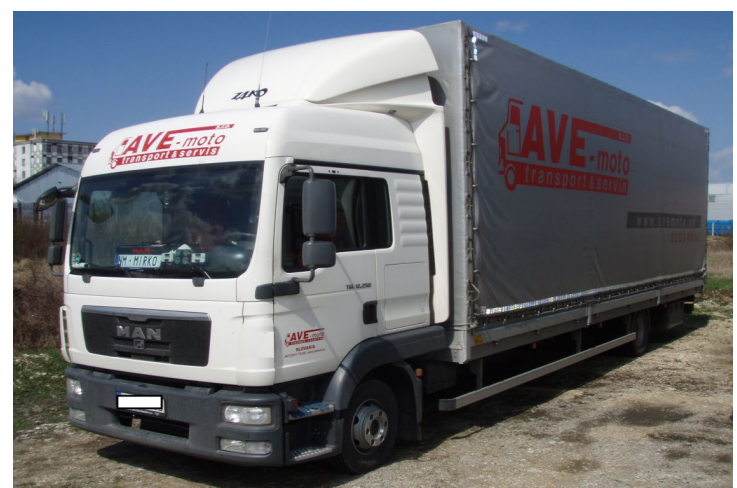

Fig. 2. Freight vehicle MAN TGL 12.250

On the other side, there are some risks connected with these vehicles. Tarpaulin platform-type body could be easily disrupted or damaged. This fact motivates thieves, who could easily steal the goods from the vehicle. From transport company point of view, there must be more attention paid to binding the tarpaulin platform-type body while loading or unloading. Riding with insufficient fixation of tarpaulin platform-type body should cause these negative factors:

- Increased fuel consumption (increased air resistance caused by air flowing to loading space),

- Air flowing to loading space (danger for goods),

- Depreciation of loading space in case of bad weather,

- Depreciation of tarpaulin platform-type body (destruction of the body and costs for new body).

\section{Test velocity}

Test velocity of freight vehicle must be at such level, that results would be reliable with emphasis on accuracy. Higher velocity means that air resistance is increasing therefore measuring gives smaller inaccuracy in result values of air resistance coefficient. Test velocity must be set considering to communication profile and adhering speed limit. Movement was evaluated in speed interval 85 $-60 \mathrm{~km} \cdot \mathrm{h}^{-1}$ for measuring air resistance coefficient.

\section{Atmospheric conditions}

Due to STN 300554 standard, these atmospheric conditions must be adhered:

- Air temperature from 5 to $25^{\circ} \mathrm{C}$,

- Air pressure from 97,33 to $101,25 \mathrm{kPa}$,

- Maximum wind force $1.5 \mathrm{~m} \cdot \mathrm{s}^{-1}$.

Air temperature was measured by thermometer during each repetition. Air pressure was measured by meteostation and it was also verified by Institute of hydrometeorology of Slovak republic. Wind force was observed by anemometer during each repetition. This device observed average wind force in time of 60 seconds. 


\section{Recording device - GPS}

GPS recording device was used for calculation of deceleration. This equipment gave information about velocity depending on time. It could record the velocity each second. The difference of these velocities means deceleration value. This quantity is immediate therefore it is necessary that the recording device GPS must work at high frequency and it must be exact.

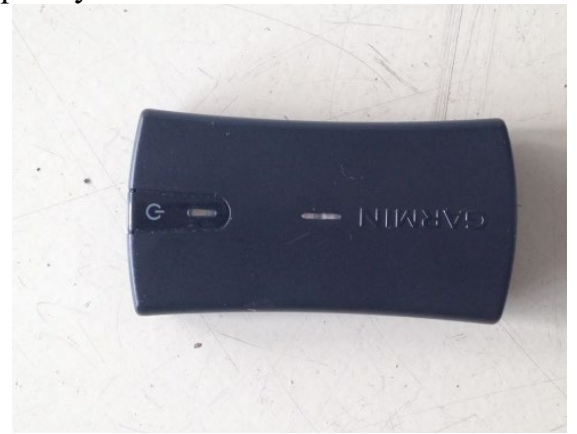

Fig. 3. Recording device GPS

Measurement no. 1 - tarpaulin in normal operating condition

First measurement was done with tarpaulin platform-type body properly fixated on all sites. It was the measurement of air resistance coefficient on freight vehicle with tarpaulin platform-type body, which was done with operating parameters, without any load. The measurement would be the most accurate therefore there were 10 repetitions for this type of measuring.

\section{Measurement no. 2 - unfolded tarpaulin on rear part of body}

In the second measurement, there was done the coast down test of freight vehicle with tarpaulin platform-type body totally unfolded on the rear part. Unfolded tarpaulin is shown in the picture below.

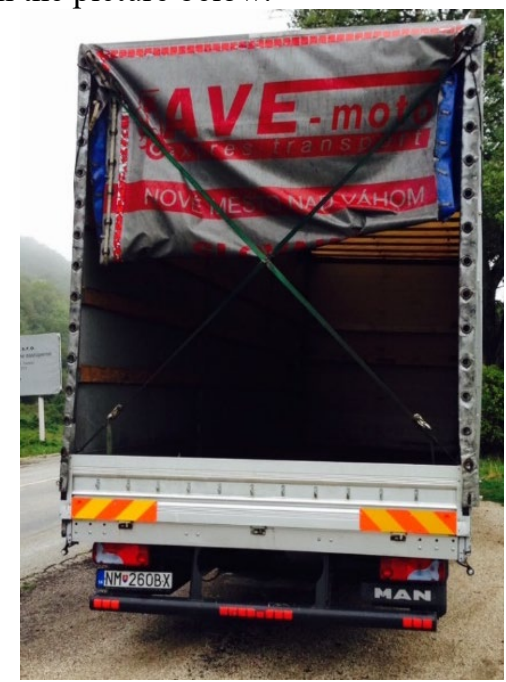

Fig. 4. Freight vehicle with unfolded tarpaulin on the rear part Driving with freight vehicle that have unfolded tarpaulin is usually used when the load overhang the loading space. Occasionally, this event could happen when driver forget to return the tarpaulin to primary condition after loading or unloading. Other cases are also when the driver forget to fix it or let it be for saving time to another manipulation.

The aim of this measurement was to refer the increasing of air resistance coefficient opposite to driving with tarpaulin in normal position. Increment of this value is caused by turbulent winds, which arise from air flowing on outlines of vehicle rear parts. These air flows are swirling what causes turbulences. In this case, air flow penetrates to loading space and it creates the zone of high vacuum, which pulls the vehicle behind. This air resistance increment is subsequently causing increment of fuel consumption.

\section{Measurement no. 3 - partly unfolded tarpaulin on side part \\ In the third measurement, there was the coast down} test done with partly unfolded tarpaulin on side part of the body, what is showed in the picture below.

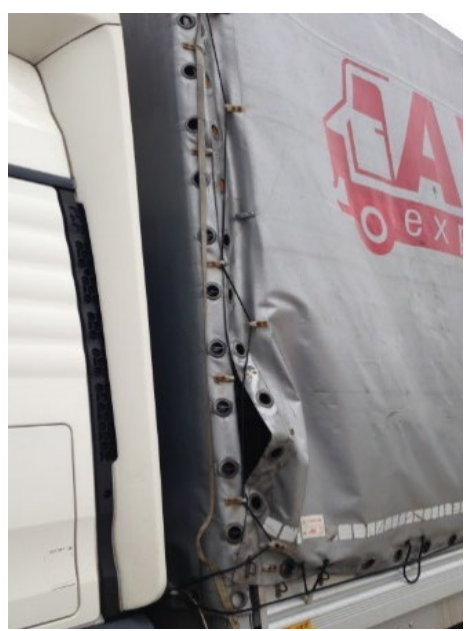

Fig. 5. Partly unfolded tarpaulin

This instance where there is partly unfolded tarpaulin on side part of the body occurs more often in real operation. It means that binding rope is not passing through all holes therefore there are some gaps. It is done mostly for saving driver's time or saving time during loading and unloading. When the gaps are larger, there are more problems. Some dirt from external environment can permeate to the loading space therefore there may occur depreciation of loading space and tarpaulin on the freight vehicle. There is increased possibility of transported load depreciation. In these cases, there arise damage on transported load and the operator is responsible for this damage because of driver's negligence.

\section{Measurement no. 4 - totally unfolded tarpaulin on side part}

In the last measurement, there was done the coastdown test with freight vehicle with totally unfolded tarpaulin on side part of the body what is showed in the picture below. 


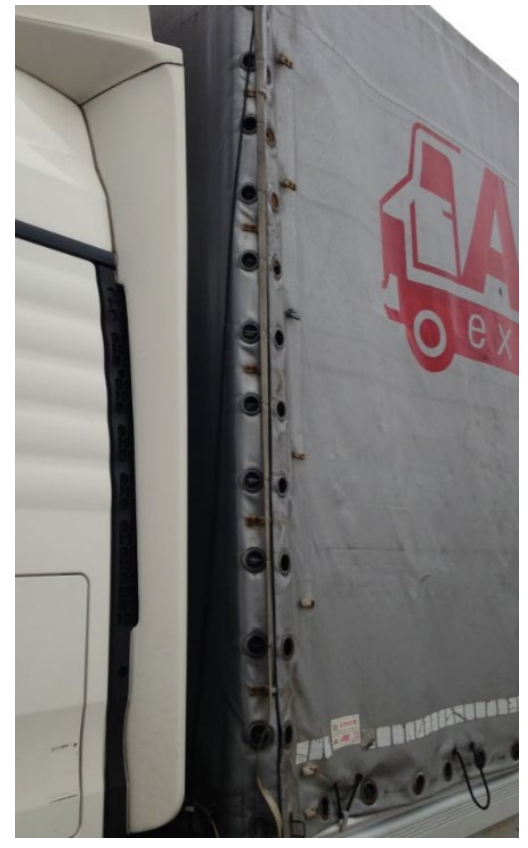

Fig. 6. Freight vehicle with totally unfolded tarpaulin on side part of the body

In this measurement, the tarpaulin was totally unfolded on side part on the body of freight vehicle. In case of freight vehicle increasing velocity, the tarpaulin was losing its original position because the air flows were very strong. Tarpaulin was lifted up because of this. Loading space was uncovered on side part of the freight vehicle body and the air resistance overpressure zone was there.

Table 2. Tarpaulin fixation influence to vehicle resistance

\begin{tabular}{|c|c|c|c|c|c|}
\hline & \multirow{2}{*}{$\begin{array}{c}\text { Tarpauilin } \\
\text { position }\end{array}$} & $\mathrm{C}_{\mathrm{d}}(-)$ & $\begin{array}{c}\mathrm{C}_{\mathrm{d}} \\
\text { growth } \\
(\%)\end{array}$ & \multicolumn{3}{|c|}{\begin{tabular}{c}
\multicolumn{3}{|c|}{ Overall growth of resistance } \\
\cline { 4 - 6 }
\end{tabular}} & & $\begin{array}{c}50 \\
\mathrm{~km} \cdot \mathrm{h}^{-1}\end{array}$ & $\begin{array}{c}70 \\
\mathrm{~km} \cdot \mathrm{h}^{-1}\end{array}$ & $\begin{array}{c}90 \\
\mathrm{~km} \cdot \mathrm{h}^{-1}\end{array}$ \\
\hline $\begin{array}{c}\text { Correct } \\
\text { state }\end{array}$ & 0,538 & - & - & - & - \\
\hline $\begin{array}{c}\text { Unfolded } \\
\text { rear part }\end{array}$ & 0,564 & 4,8 & 2,2 & 3 & 3,3 \\
\hline $\begin{array}{c}\text { Partly } \\
\text { unfolded } \\
\text { side part }\end{array}$ & 0,545 & 1,3 & 0,7 & 0,9 & 1 \\
\hline $\begin{array}{c}\text { Totally } \\
\text { unfolded } \\
\text { side part }\end{array}$ & 0,633 & 17,6 & 9,15 & 11,5 & 13 \\
\hline
\end{tabular}

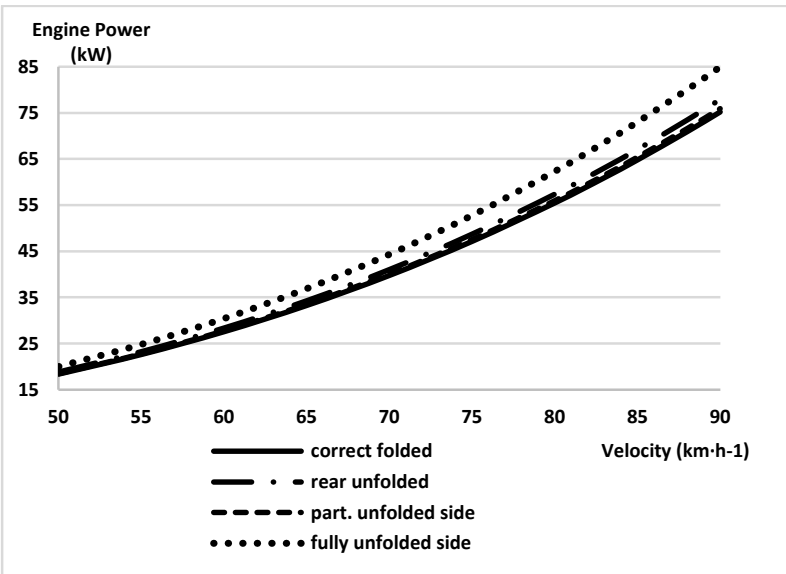

Fig. 7. Engine power according to tarpaulin fixation

\section{Measurement conclusion}

Measurement results prove the impact of fixation and position of tarpaulin and its parts to air resistance. When some parts of tarpaulin are looser fixated and there are possibilities to create 'bubbles, gaps' or freely 'waving" parts, the air resistance of vehicle is increasing. This effect influence fuel consumption. It is very hard to quantify this impact, because there are other factors instead of air resistance, such as losses in driveline, engine characteristics (efficiency process consider to turning load, specific fuel consumption). However, it could be stated, that immediate fuel consumption of this type of vehicle corresponds with percentage change of air resistance what is showed in table 2. It is not about average fuel consumption for entire vehicle operation, because it is only about immediate consumption at selected speed.

Air resistance coefficient value $c_{d}$ was identified by measurement of coast down test for freight vehicle with tarpaulin platform-type body. The aims of this measurement was reviewing use of this method for measuring air resistance coefficient and refer to change of this value at different operational conditions of tarpaulin platform-type body on freight vehicle use in praxis.

\section{Acknowledgment}

This article was created to support project named as:

6/KCMD/2018 - Vplyv aerodynamických vlastností vozidiel v cestnej doprave na ich prevádzku $(6 / \mathrm{KCMD} / 2018$ - Influence of road vehicles aerodynamical characteristics on their operation)

And

Centre of excellence for systems and services of intelligent transport II.,

ITMS 26220120050 supported by the Research \& Development Operational Programme funded by the ERDF. 

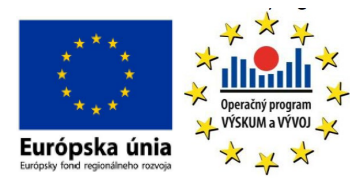

\section{AÝsKumáná}

Authors of this paper thank to AVE-moto company for providing vehicle and technical background to do the measurement.

\section{References}

Hausberger S. et al. 2011 Evaluation of fuel efficiency improvements in the Heavy-Duty Vehicle (HDV) sector from improved trailer and tire designs by application of a new test procedure. TU Graz, Graz, 2011.

Jazar R. 2009 Vehicle Dynamics, Theory and applications. Springer Science + Bussines Media, 2009.

Kalina, T. et al. 2017 Comparison of economic efficiency of LNG with traditional fuels in freight transport. In: Proceedings of the 21 tst international scientific conference Transport means 2017, Kaunas, Lithuania, pp. 213-219.

Kalincak, D., Bartik, L., Grencik, J. 2012 The hybrid traction the way of fuel utilization improvement. In: Facta universitatis-series mechanical engineering, Nis, Serbia, 2012, Vol. 10, Issue 2, pp. 163-170.

Knez, M., Jereb, B., Obrecht, M. 2014 Factors influencing the purchasing decisions of low emission cars: A study of Slovenia. In: Transportation research part D - Transport and environment, 2014, Vol. 30, pp. 53-61. DOI: 10.1016/j.trd.2014.05.007.

Kobryn, J., Figlus, T. 2010 Similarity numbers in the-zone combustion model. In: Scientific journal of Silesian university of technology-series transport, Gliwice, Poland, 2010, Vol. 67, pp. 75-82.

Matuszak, Z. 2012 Components validity evaluation in a complex technical structure. In: Scientific journals of the Maritine university of Szczecin-zeszyty naukowe Akademii morskej $w$ Szczecinie, 2012, Vol. 32, Issue 104, pp. 115-122.

Mruzek M. et al. 2016 Analysis of parameters influencing electric vehicle range. In: Procedia Engineering, 134/2016, pp. 165-174.

Polcar, A., Cupera, J., Kumbar, V. 2016 Calibration and its use in measuring fuel consumption with the can-bus network. In: Acta Universitatis Agriculturae et Silviculturae Mendelianae Brunensis, 2016, Vol. 64, Issue 2, pp. 503507.

Rakovska, M. 2016 Characteristics of Logistics Outsourcing in Bulgaria: The Perspectives of the Logistics Service Providers and their Customers. In: Logistics \& Sustainable Transport, Volume 7, Issue 1, Pages 18-27, ISSN 22324968, DOI: https://doi.org/10.1515/j1st-2016-0002

Rievaj, V., Mokrickova, L., Rievaj, J. 2016 Impact of driving techniques on fuel consumption. In: Communications Scientific Letters of the University of Zilina, 2016, Vol. 18, Issue 2, pp. 72-75.

Sdoukopoulos, E., Boile, M., Anagnostopoulou, A. 2015 Estimating truck operating costs for domestic trips - case studies from Greece. In: Logistics \& Sustainable Transport, Volume 6, Issue 1, Pages 41-49, ISSN (Online) 2232-4968, DOI: https://doi.org/10.1515/jlst2015-0010.

Skrucany, T., Sarkan, B., Gnap, J. 2016 Influence of Aerodynamic Trailer Devices on Dragreduction Measured in a Wind Tunnel. In: Eksploatacja i niezawodnosc Maintenance and reliability, vol. 18, 1/2016, pp.151-154.

Standard STN 30 0554. Road motor vehicles. Coastdown test of road motor vehicles. (Slovakia).

Van der Krieke J., Van Raemdonck G. 2014 Analyzing Fuel Savings of an Aerodynamic Drag Reduction Device with the Aid of a Robust Linear Least Squares Method. In: SAE Int. J. Commer, vol. 7, 2/2014, pp. 675-684.

Vrábel, J. et al. 2017 Influence of Emergency Braking on Changes of the Axle Load of Vehicles Transporting Solid Bulk Substrates. In: Transbaltica 2017: Transportation science and technology. Vol: 187, 2017, pp: 89 - 99. DOI: 10.1016/j.proeng.2017.04.354. 